\title{
SOIL COMPACTION AND WATERPROOFING AND IMPLICATIONS IN URBAN FLUVIAL CHANNELS
}

\author{
https://doi.org/10.4215/rm2020.e19023 \\ Elizon Dias Nunes $\mathrm{a}^{*}$ - Lucas Espíndola Rosa ${ }^{\mathrm{b}}$
}

(a) PhD in Geography. Professor at Federal University of Goiás (UFG), Goiânia (GO), Brazil.

ORCID: https://orcid.org/0000-0001-5430-4841. LATTES: http://lattes.cnpq.br/4537975818670608.

(b) PhD in Geography. Professor at Federal University of Goiás (UFG), Goiânia (GO), Brazil.

ORCID: https://orcid.org/0000-0002-2979-6546. LATTES: http://lattes.cnpq.br/6482962736631878.

\author{
Article history: \\ Received 27 March, 2020 \\ Accepted 10 August, 2020 \\ Publisher 15 October, 2020
}

\section{(*) CORRESPONDING AUTHOR}

Address: Avenida Esperança, s/n, sala A-37 BI. A, 1 Andar, CEP 74690-900, Câmpus Samambaia, Goiânia (GO), Brasil. Phone: (+55 62) 3521 1184, ramal 211.

E-mail: elizonnunes@ufg.br

\begin{abstract}
Urban expansion and densification have resulted in phenomena related to the degradation of watersheds. This work evaluated the influence of increased anthropic pressure on the imbalances involving erosive processes and the consequent degradation of the river plain of a hydrographic basin in Aparecida de Goiânia - GO. The methodology analyses the spatial-temporal correlation between reduced concentration time, increased runoff estimates, and the consequent degradation of the plain in 1992,2005, and 2016. The results indicate an increase in erosion in segments of channel convergence, with a low altimetric gradient and the occurrence of Fluvent Entisol, stemming from the increase in volume and flow peaks arising from areas with significant densification processes in the last twenty-four years. Thus, the importance of using indicators of increased anthropic pressure to understand the impacts related to urban density.
\end{abstract}

Keywords: Urban Density; Surface runoff; River Erosion.

\section{Resumo / Resumen}

\section{COMPACTAÇÃO E IMPERMEABILIZAÇÃO DO SOLO E IMPLICAÇÕES NOS CANAIS FLUVIAIS URBANOS}

A expansão e o adensamento urbano vêm implicando em fenômenos relacionados à degradação de bacias hidrográficas. O objetivo deste trabalho é avaliar a influência do aumento da pressão antrópica nos desequilíbrios envolvendo processos erosivos e a consequente degradação da planície fluvial de uma bacia hidrográfica em Aparecida de Goiânia - GO. A metodologia compreendeu a correlação espaço-temporal entre redução do tempo de concentração, aumento das estimativas de escoamento superficial e a consequente degradação da planície em 1992, 2005 e 2016. Os resultados indicam aumento de erosões em segmentos de convergência de canais, de baixo gradiente altimétrico e ocorrência de Neossolo Flúvico, resultantes do aumento do volume e picos de vazão advindos de áreas com significativo processo de adensamento nos últimos 24 anos. Assim, destaca-se a importância do uso de indicadores de aumento da pressão antrópica na compreensão de impactos relacionados ao adensamento urbano.

Palavras-chave: Adensamento Urbano; Escoamento Superficial; Erosão Fluvial.

\section{COMPACTACIÓN E IMPERMEABILIZACIÓN DEL SUELO E IMPLICACIONES EN CANALES FLUVIALES URBANOS}

La expansión y la densificación urbana han dado lugar a fenómenos relacionados con la degradación de las cuencas hidrográficas. El objetivo de este trabajo es evaluar la influencia del aumento de la presión antrópica sobre los desequilibrios que involucran procesos de erosión y la consecuente degradación de la llanura aluvial de una cuenca hidrográfica en Aparecida de Goiânia - GO. La metodología comprendió la correlación espacio-temporal entre la reducción del tiempo de concentración, el aumento de las estimaciones de escorrentía y la consiguiente degradación de la llanura en 1992, 2005 y 2016. Los resultados indican un aumento de erosiones en los segmentos de convergencia del cauce, con un gradiente altimétrico bajo y presencia de Neosuelo Flúvico, como resultado del aumento del volumen y de los picos del caudal que surgen de las áreas con un proceso de densificación significativo en los últimos 24 años. Así, se destaca la importancia del uso de indicadores de aumento de la presión antrópica para comprender los impactos relacionados con la densificación urbana.

Palabras-clave: Densificación Urbana; Escorrentía Superficial; Erosión Fluvial. 


\section{INTRODUCTION}

In recent decades, urban expansion and densification have led to a series of changes, especially in the rate of environmental processes, resulting in phenomena related to the increase in anthropic pressure in river basins. These alterations have led to the degradation of these natural systems, especially in large cities, where the increase in each household's built area has contributed to the general reduction of places destined for infiltration, preventing the soil from performing its hydrological functions efficiently (NUNES, L. 2015; TUCCI, 2016). Among the main impacts arising from this scenario are the removal of vegetation cover from environmentally sensitive areas and the consequent change in the functioning of ecosystems, leading to a loss of biodiversity and a change in the pace of physical processes (HAMMOND et al., 2013; LIN et al., 2017; GUZHA et al., 2018).

Hydrological processes, which result from the interaction of rainwater with the properties of the terrain and soil, are the most prominent of these. On a daily basis, they create adverse situations that produce harmful effects. On the whole, these effects are caused by the occurrence of long-term, mainly intense rains, combined with absent or inefficient infrastructures, such as drainage systems and poorly planned streets that, associated with compaction and waterproofing, reduce the capacity of soils to develop their hydrological functions. Inefficient infiltration and water retention processes in the subsurface are the most significant, as they influence the increase in surface runoff, alter the flows between the water table and drainage channels, causing overflow in rainy periods and consequently, impair the system's continuity during droughts (SU et al., 2014; MOHAJERI et al., 2015).

Another factor that influences the concentration and increased volume of flow is the form of urban expansion and densification, which tends to start at the highest and widest parts of the basins and, in most cases, extends to the lowest segments closest to the floodplains. As a result, the runoff has a higher volume and speed, converging and affecting smaller areas. Furthermore, the reduction in the concentration time implies an increase in intensity and, therefore, greater pressure in the lower areas. For geometric reasons, they tend to decrease exponentially as they approach the springs and river channels, increasing the difference between producing areas and areas receiving flows. Given the heavy and fleeting rains, especially in large Brazilian urban centers (WOLLMANN, 2015), the number and frequency of floods have risen in recent years (LIMA; AMORIM, 2014; KOCORNIK-MINA et al., 2015; MUKHERJEE, 2016; GRIFFITHS et al., 2018).

In Brazil, this phenomenon was more apparent after the 1960s, when most of the population moved to the cities at the expense of the countryside (OJIMA, 2008; TUCCI, 2016; PASQUALOTTO; SENA, 2017). The demand for new housing in urban environments influenced the expansion of adjacent areas and led to the densification of existing urbanized central regions, as well as the occupation of less satisfactory areas. The result was an increased and more intense modification, especially of the soil cover and, consequently, greater interference in the balance of natural systems (CAMARGO; AMORIM, 2005; SANTOS et al., 2017). In this context, Tripathi et al. (2014) and Rubinato et al. (2018) take into account global social, economic, climatic, and urban expansion trends and suggest that the frequency, magnitude, and, above all, the costs related to these events will tend to rise.

Nevertheless, given all these implications, currently, there is still a lack of established relevant and safe indicators to guide more harmonious occupations and, thus, ensure a lower-impact urban growth (SILVA; TRAVASSOS, 2008; WEBBER et al., 2018). Clearly, the solution is to find a better equation between the factors influencing the modified areas that produce greater energy inputs and the subsequent effects in the receiving areas that still have natural characteristics, to mitigate the imbalances in urban hydrographic systems.

This article aims to evaluate the effects of urban density on the increase of effective precipitation, as well as on the spatial-temporal concentration of the runoff volume estimates and their impact on the balance of river channels in the years 1992, 2005, and 2016 in the hydrographic basin of the Tamanduá stream in the municipality of Aparecida de Goiânia - GO, Brazil. The research is pertinent as in the Metropolitan Region of Goiânia, the number of river channels affected and the intensity of their degradation in areas that have undergone urban densification in the last decades have been growing. 


\section{MATERIALS AND METHODS}

\section{STUDY AREA}

The study area is a river basin located in the urban area of Aparecida de Goiânia, as shown in Figure 1, where population growth has intensified since the 1980 s due to urban expansion. New neighborhoods have emerged in adjacent areas and the densification of buildings in partially urbanized areas or close to the major traffic routes have occurred. This area is representative of the urban expansion and densification process, especially over the last three decades and which has resulted, above all, in the municipality's conurbation with the capital of Goiás (FERREIRA, 2013; BORGES; CUNHA, 2015). Consequently, there has been a gradual process of compaction and waterproofing of the soil, which is spatially and temporally correlated to changes in the hydrological regime, resulting in erosive incisions along the slopes and the plain with the ensuing degradation of the river channels.

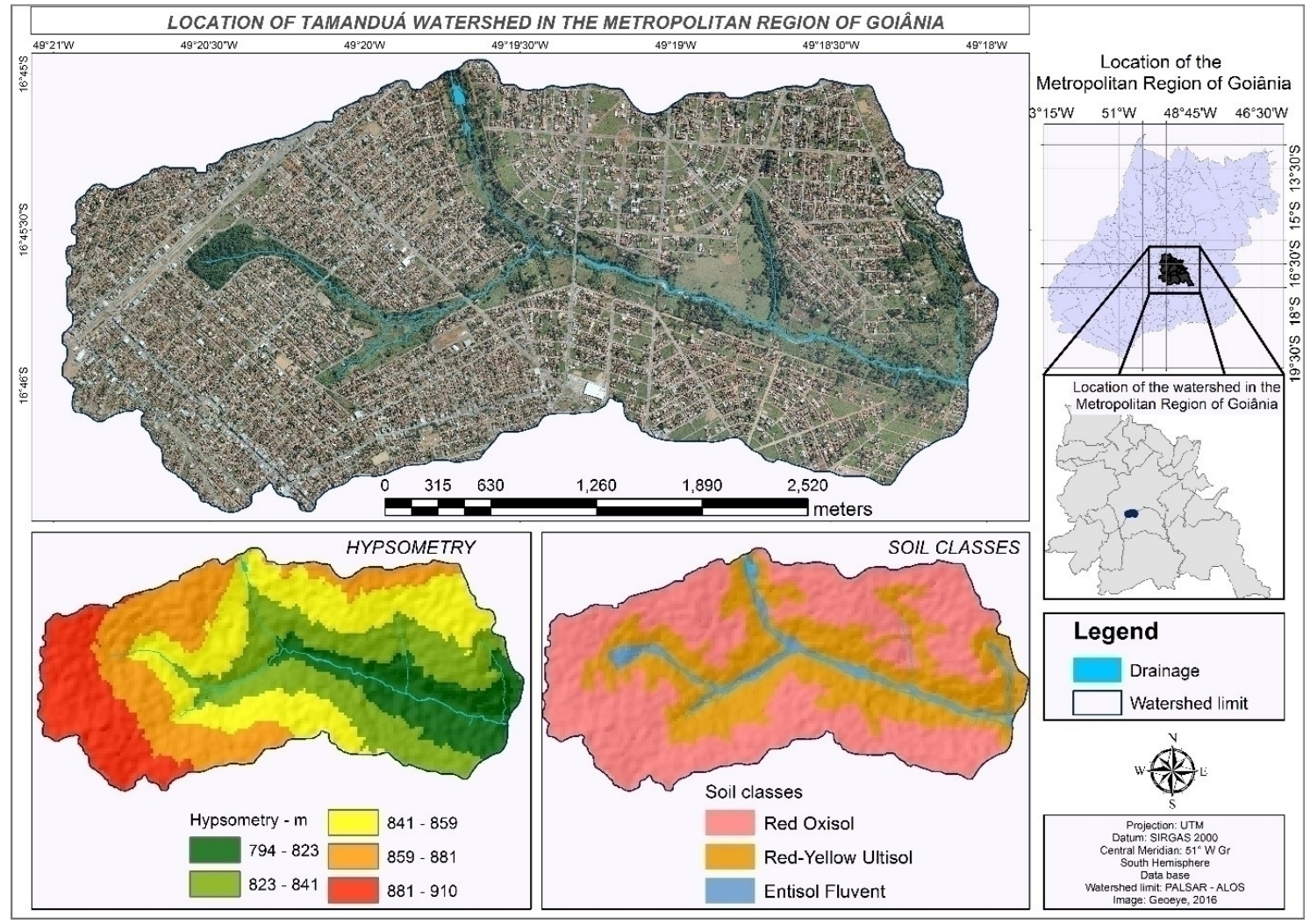

Figure 1 - Location, hypsometry, and soil classes of the Tamanduá stream basin in the city of Aparecida de Goiânia.

The area's geology is composed of metamorphic rocks belonging to the Araxá Sul de Goiás group, with a predominance of schist that occupies a large part of the basin and outcrops along the main channel. Quartzites rich in quartz and variable concentrations of micas also occur (LACERDA FILHO et al., 1999; FUCK et al., 2000). This geology means the main channel has a strong resistance to deepening, giving it a low altimetric gradient, which promotes the occurrence of alluvial and hydromorphic soils. A declivity of 5\% predominates in the higher segments of the slopes, with a preponderance of Dystrophic Red Oxisol and clay texture (RODRIGUES et al., 2005). These were the first areas to undergo the soil compaction and waterproofing process due to the construction of the first groups of buildings and the first compacted roads in the 1970s and 1980s (PINTO, 2009). In the transition area from high to medium slopes, the declivity rises to $11 \%$, with a predominance of Red-Yellow Ultisol with a medium to clay texture. In 1980 these areas were still occupied by pasture, as the building process was still restricted to the highest and flattest areas. Finally, in the vicinity of the river channels, the declivity rises to about $28 \%$ before decreasing again when it reaches the plain, 
remaining around 3\% along the entire river channel. On this low slope, Entisol Fluvent with sandy texture predominates, sometimes overlying the Dystrophic Alfisol and clay texture. Overall, in terms of geomorphological processes and forms, it is a basin with mainly convex slopes and not much concavity, even close to the floodplain.

The climate is semi-humid tropical, with two distinct seasons and marked climatic seasonality (MONTEIRO, 1951; LUIZ; ROMÃO, 2019). The warm and rainy period, with average temperatures between $29^{\circ} \mathrm{C}$ and $32^{\circ} \mathrm{C}$, is from the end of September to the beginning of April, with January and December having the highest accumulated average precipitation with $268 \mathrm{~mm}$. The dry and mild period, with average temperatures between $18^{\circ} \mathrm{C}$ and $21.5^{\circ} \mathrm{C}$, lasts from May to the beginning of September, with the average of the lowest accumulated precipitation values, $8 \mathrm{~mm}$, occurring in June and July. The average annual precipitation is $1,572 \mathrm{~mm}$, and in years of less rainfall, this can fall to $1236 \mathrm{~mm}$, while in years with greater accumulated precipitation it reaches around 1900, and can exceptionally peak at 2,080 accumulated mm (OLIVEIRA et al., 2014; INMET, 2017).

\section{METHODOLOGY}

The methodology covered the spatial-temporal correlation between the increased volume and the reduced concentration time of surface runoff in the river basin area and the degradation by edge erosion throughout the river plain from 1992 to 2016 . The runoff estimates were determined using the Rational Method hydrological model, whose first systematized records were produced by Pierre Parrault in the seventeenth century. These principles were subsequently adapted by Mulvaney (1851) and Kuichling (1889). One of the most well-known formulas is expressed by the following equation:

\section{$Q \max =\mathrm{CiA} / 3.6$}

Equation 1

where $\mathrm{Qmax}=$ maximum runoff flow, estimated in $\mathrm{m}^{3} / \mathrm{s} ; \mathrm{C}=$ runoff coefficient or the ratio between the drained volume and the precipitated total, adimensional; $i=$ average of the maximum intensities of precipitation, in $\mathrm{mm} / \mathrm{h}$, to estimate the maximum flow in the outlet in question, the duration of the rainfall event must be equal to or greater than the time necessary for the entire basin to contribute with runoff; $\mathrm{A}=$ watershed area, in $\mathrm{km}^{2}$; and 3.6 = conversion factor between units.

\section{RUNOFF COEFFICIENTS}

The runoff coefficients were determined based on the proposal of the Soil Conservation Service (SCS) of the United States Department of Agriculture (1971). This proposal was reviewed and applied by the Federal Highway Administration (FHA) - US Department of Transportation (2013), and is the ratio between the effective precipitation, or volume converted to surface runoff, and the total precipitation during the event in question, as presented in the following equation:

$$
C=\left[\frac{(p-0,2 s)^{2}}{(p+0,8 s)}\right] / P
$$

Equation 2

When $\mathrm{C}=$ runoff coefficient, dimensionless; $\mathrm{P}=$ rainfall or pluviometric height in $\mathrm{mm} ; \mathrm{s}=$ coefficient or potential for water storage in the soil, in $\mathrm{mm}$; and Ia $=>0.2 \mathrm{~s}=$ initial abstraction or loss considered. As observed in the first part of Equation 2, for effective precipitation an initial loss of about $20 \%$ of the precipitated volume is considered due to interception and retention in depressions. This implies that rainfall with an accumulated volume below $20 \%$ of the storage coefficient does not make surface runoff available.

The values of s were estimated based on the $\mathrm{CN}$ values (flow number), according to the Natural Resources Conservation Service (NRCS) - USDA (1997), as expressed in equation 3: 


$$
S=\frac{25400}{C N}-254
$$

Equation 3

Therefore, the $\mathrm{CN}$ values were determined based on the assessment of hydrological groups (GH), resulting from the assessment of soil types, in particular, texture and depth, the coverage and use conditions, and the antecedent humidity. In this method, the $\mathrm{CN}$ values range from 0 (low flow capacity) to 100 (high flow capacity). It is noteworthy that the calculation also considered intermediate humidity soil conditions, with the accumulated precipitation varying between 13 and $53 \mathrm{~mm}$ in the previous five days.

The land cover and use maps were elaborated using the sequential and logical evaluation of aerial photographs from 1992 in shades of gray and a spatial resolution of $33 \mathrm{~cm}$, and colored images from the QUICKBIRD and GEOEYE satellites, from 2005 and 2016 respectively, with $50 \mathrm{~cm}$ spatial resolution. Supervised classification was adopted by grouping adjacent pixels and those with similar spectral characteristics, spectral detail of 18 and spatial detail of 8 , both on a scale from 1 to 20 , and a minimum segment or grouping of 4 pixels. The field validations took place through visits to representative sites of each class and in areas that had remained unchanged throughout the period. The erosive processes were mapped through visual inspection, based on the same images. The use of extremely high spatial resolution images is especially efficient in determining classes with different coverage and use conditions and, consequently, has a better detailing of the waterproofing levels, as verified by Lechiu et al. (2012).

\section{MEAN MAXIMUM PRECIPITATION INTENSITIES}

The averages of the maximum precipitation intensities were estimated according to Vilela and Mattos (1975) proposal, which relates the intensity - duration - frequency (IDF) of the meteorological events. To this end, the equation proposed by Oliveira et al. (2005) was used, which results from the systematized rainfall history for the Goiânia region through the following relationship:

$$
\operatorname{Im}=\frac{\mathrm{K} \times \operatorname{Tr}^{\mathrm{a}}}{(\mathrm{t}+\mathrm{b})^{\mathrm{c}}}
$$

Equation 4

Where $\mathrm{Im}=$ average of the maximum precipitation intensities, in $\mathrm{mm} / \mathrm{h}, \mathrm{K}, \mathrm{a}, \mathrm{b}$ and $\mathrm{c}=$ specific parameters for the climatological station; $\mathrm{T}=$ time of return, in years for an extreme event; and $\mathrm{t}=$ time of concentration of runoff which must be less than or equal to the duration of precipitation in the basin area, in minutes. The present work considers a return time of 12 years, compatible with commercial areas and arterial traffic routes (PORTO et al., 2004). The duration times of the precipitation resulted from the time of concentration of the runoff, for the entire basin, estimated for the years 1992, 2005, and 2016. These were determined by the Cinematic Method, according to the SCS-USDA (1971) using the following equation:

$$
T c=1 / 60 x \Sigma \frac{L i}{V i}
$$

Equation 5

Where $\mathrm{Tc}=$ Time of concentration of runoff, in min; 1/60 transformation factor from seconds to minutes; $\mathrm{Li}=$ flow length in the considered segment, in $\mathrm{m}$; and $\mathrm{Vi}=$ Runoff speed, in $\mathrm{m} / \mathrm{s}$.

The runoff speed was estimated based on the evaluation of the $\mathrm{K}$ coefficients and the declivity, using the following equation (PORTO, 1995): 


$$
\mathrm{Vi}=\mathrm{K} \times \mathrm{Si}^{0.5}
$$

Equation 6

Where $\mathrm{Vi}=$ runoff speed, in $\mathrm{m} / \mathrm{s} ; \mathrm{K}=$ coefficient, according to the Manning roughness coefficient $\mathrm{n}$ and hydraulic radius, adimensional; and $\mathrm{Si}=$ declivity, in $\mathrm{m} / \mathrm{m}$, raised to the exponent 0.5 .

As the basin's area is greater than $3 \mathrm{~km}^{2}$, the results of the Rational Method were applied with a delay coefficient as a function of its area, resulting in what is known as the Modified Rational Method, as proposed by Euclydes (1987), whose formula is:

$$
\theta=0.278-0.00034 \mathrm{~S}
$$

Equation 7

Where $\theta=$ delay coefficient as a function of the basin area; 0.278 and 0.00034 are constant and $\mathrm{S}$ $=$ area of the basin in $\mathrm{km}^{2}$.

\section{WATERSHED CONTRIBUTION AREA}

The slope, flow length, and basin area models were created using the ALOS - PALSAR Elevation Model (MDE), corrected and with a spatial resolution of 12.5 meters. The basin's variable area was used cumulatively, that is, the volume of cells upstream was transferred to those downstream, resulting in the accumulation of surface runoff as a function of the specific contribution area (NUNES; BORBA, 2018). This enabled the application of all the equations and, consequently, all the calculations for each of the $65,89412.5 \mathrm{~m}^{2}$ cells of the basin's MDE, which were used to create a spatially distributed model, with the highest value flow estimate corresponding to the river mouth. Otherwise, there would only have been one calculation and the resulting value would represent the entire area of the basin, and the spatial variability of runoff volumes would not be represented.

\section{ESTIMATES OF PRESSURE ON THE RIVER PLAIN}

To calculate the pressure on the river plain and the consequent erosion of the edges of the channels during rainfall, the formula for the concept of kinetic energy or energy of a given mass in motion was applied using the following equation:

$$
E c=m * v^{2} / 2
$$

Equation 8

Where $E c=$ kinetic energy of the flow, in $j ; m=$ mass represented by the volume of runoff and considering the water density equal to 1 ; and $\mathrm{v}=$ speed of runoff, in $\mathrm{m} / \mathrm{s}$.

\section{RESULTS AND DISCUSSION}

\section{URBAN DENSITY THE INCREASEIIN RUNOFF
COEFFICIENTS, AND EFFECTIVE PRECIPITATION RUNOF}

The results, especially from the application of Equations 2 and 3, and considering a precipitation intensity of $73.37 \mathrm{~mm} / \mathrm{h}$ for 32.42 minutes for the year 2016, are shown in Table 1. It presents the relationship between the mapped classes of land cover and use, the hydrological groups (GH), and the $\mathrm{CN}$ values. The results are the values of the infiltration coefficients (s), Effective Precipitation, and Runoff Coefficients. It is significant that in addition to the conditions of coverage and use, the last two 
values depend on the duration time, as well as the precipitation intensity considered in relation to the infiltration coefficients.

\begin{tabular}{|c|c|c|c|c|c|}
\hline Condition of the Terrain & GH & $\mathrm{CN}$ & $\mathbf{S}-\mathbf{m m}$ & $\begin{array}{c}\text { Effective Precipitation } \\
\text { (mm) }\end{array}$ & $\begin{array}{c}\text { Superficial Runoff } \\
\text { Coefficient }\end{array}$ \\
\hline \multirow{3}{*}{ Built Area } & $\mathrm{A}$ & 77 & 75.87 & 5.96 & 0.150 \\
\hline & $\mathrm{C}$ & 90 & 28.22 & 18.57 & 0.468 \\
\hline & $\mathrm{D}$ & 92 & 22.08 & 21.64 & 0.546 \\
\hline Paved surface & $\mathrm{A}, \mathrm{C}, \mathrm{D}$ & 98 & 5.18 & 3403 & 0.858 \\
\hline \multirow{3}{*}{ Compacted Exposed Soil } & A & 72 & 98.77 & 3.33 & 0.084 \\
\hline & $\mathrm{C}$ & 87 & 37.95 & 14.67 & 0.370 \\
\hline & $\mathrm{D}$ & 89 & $31: 39$ & 17.18 & 0.433 \\
\hline \multirow{3}{*}{ Uncompacted Exposed Soil } & A & 49 & 264.36 & 0.00 & 0.00 \\
\hline & $\mathrm{C}$ & 79 & 67.51 & 7.29 & 0.184 \\
\hline & $\mathrm{D}$ & 84 & $48: 38$ & 11.45 & 0.289 \\
\hline \multirow{3}{*}{ Compacted Grasses } & A & 39 & 397.28 & 0.00 & 0.000 \\
\hline & $\mathrm{C}$ & 74 & 89.24 & 4.27 & 0.107 \\
\hline & $\mathrm{D}$ & 80 & 63.50 & 8.02 & 0.202 \\
\hline \multirow{3}{*}{ Uncompressed Grasses } & $\mathrm{A}$ & 30 & 592.66 & 0.00 & 0.000 \\
\hline & $\mathrm{C}$ & 71 & 103.74 & 2.90 & 0.073 \\
\hline & $\mathrm{D}$ & 78 & 71.64 & 6.60 & 0.166 \\
\hline \multirow{3}{*}{ Isolated Trees } & $\mathrm{A}$ & 56 & 199.57 & 0.00 & 0.000 \\
\hline & $\mathrm{C}$ & 86 & 41.34 & 13.53 & 0.341 \\
\hline & $\mathrm{D}$ & 91 & 25.12 & 20.05 & 0.506 \\
\hline \multirow{3}{*}{ Gallery Forest } & A & 25 & 762.00 & 0.00 & 0.000 \\
\hline & $\mathrm{C}$ & 70 & 108.85 & 2.51 & 0.063 \\
\hline & $\mathrm{D}$ & 77 & 75.87 & 5.96 & 0.150 \\
\hline
\end{tabular}

Table 1 - Classes of land use and occupation, hydrological groups and respective infiltration coefficients, effective precipitation, and runoff. Source: Prepared by the authors based on constant CN data in Tucci and Marques (2001), using Equations 2 and 3.

The results of the multitemporal mapping of land cover and use classes indicate a basin undergoing an increasing process of expansion of urbanization, especially in its lower portions and close to the main channel, as well as densification of buildings in the higher and flatter areas. The pace of this process has led to a substantial increase in areas with high runoff coefficients and, consequently, high effective precipitation. Uncompressed grasses, uncompacted exposed soil, and Galley Forest were prominent among the classes where the area was reduced. The first two contributed to the increase in the Built Area, while the latter gave way to the expansion of buildings in the vicinity of the drainage channels. In both cases the Built Area increased from $16.49 \%$ in 1992 to $28.46 \%$ in 2005 , reaching $56.02 \%$ in 2016. The Compacted Exposed Soil class changed mainly to Paved Surfaces, which rose from $0 \%$ in 1992 to $9.6 \%$ in 2005, and then to $14.08 \%$ in 2016, as shown in Figure 2.

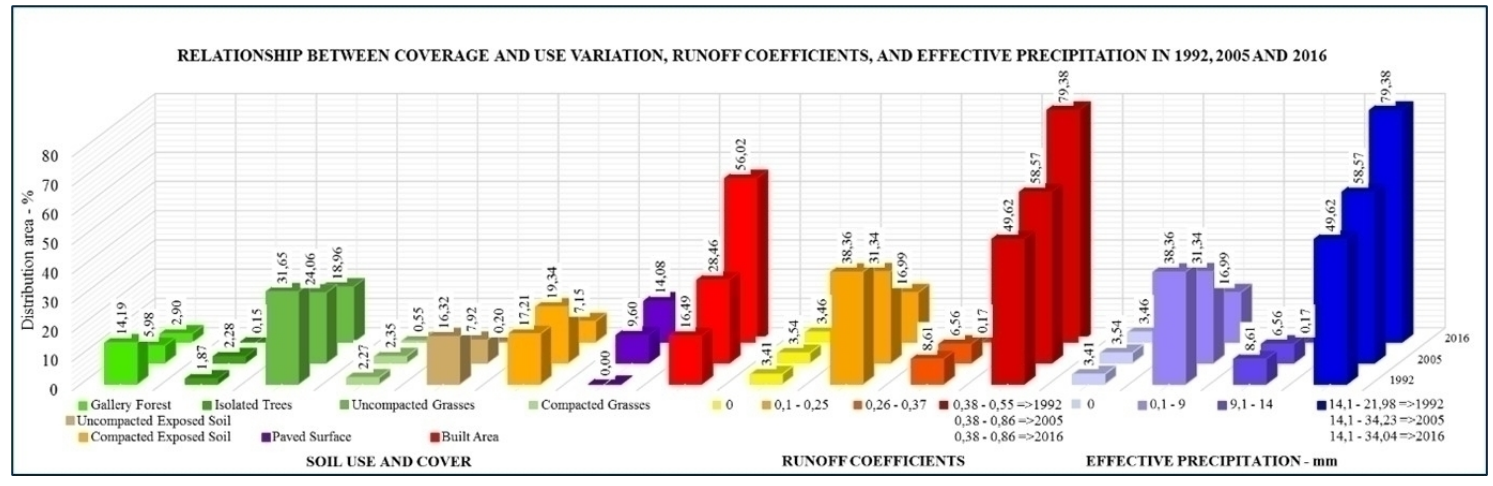

Figure 2 - Areas - \% - of each class of cover and land use, runoff coefficients, and effective precipitation in the years 1992, 2005 and 2016.

Considering the effects of expansion and urban density due to rainfall, the general trend was a reduction in areas with low flow coefficients and a consequent increase in those with values above 0.37 . This is a direct reflection of the growth in built-up areas and, mainly, the emergence of paved surfaces that raised the extreme coefficient value, from 0.55 in 1992, to 0.86 in 2005 . Taking into account the scenarios of rainfall events for 1992, 2005, and 2016, the general trend was to reduce areas with runoff 
coefficients of 0.1 to 0.25 and increase those with runoff coefficients of 0.38 to 0.86 , as well as those areas with high effective precipitation.

Thus, in 1992, the intensity of rainfall was $72.47 \mathrm{~mm} / \mathrm{h}$, during an estimated concentration time of 33.13 minutes, resulting in a pluviometric height of $40.03 \mathrm{~mm}$. In these conditions, it is clear that around $3.41 \%$ of the basin area did not provide effective precipitation; $38.36 \%$ had a flow sheet 0.1 to $9 \mathrm{~mm}$ thick, $8.61 \%$ between 9.1 and $14 \mathrm{~mm}$, and $49.62 \%$ an excess rainfall column that could reach up to $21.98 \mathrm{~mm}$, as presented in Figure 2. In 2005, based on the same figure and considering a rainfall intensity of $72.87 \mathrm{~mm} / \mathrm{h}$ for 32.81 minutes, the estimated pluviometric height was $39.85 \mathrm{~mm}$. Faced with a more advanced stage of compaction and waterproofing of the soil, it is evident that the area without effective precipitation remained almost unchanged; $31.34 \%$ had effective precipitation between 0.1 and $9 \mathrm{~mm} ; 6.56 \%$ between 9.1 and $14 \mathrm{~mm}$; and $58.57 \%$ between 14.1 and $34.23 \mathrm{~mm}$. Considering an intensity of $73.37 \mathrm{~mm} / \mathrm{h}$ during a concentration period of 32.42 minutes, the estimated rainfall in 2016 was $39.64 \mathrm{~mm}$. In these conditions, about $17 \%$ of the basin had effective precipitation between 0.1 and 9 $\mathrm{mm}$; $0.17 \%$ between 9.1 and $14 \mathrm{~mm}$; and $79.38 \%$ between 14.1 and $34.04 \mathrm{~mm}$, which means the soil's function in infiltrating and storing water, a well as regulating water flows has been severely limited.

Regarding the spatial distribution of the conditioners and the respective effects of the urban expansion and densification process, it is apparent that the increase in built areas and the appearance of paved surfaces intensified from the higher to the lower areas and closer to the drainage channels, as shown in Figure 3. For the year 1992, it is possible to verify that the high flow coefficients and their correspondence in high effective precipitation were restricted to the built and higher parts of the basin, allowing lower portions that still had low flow coefficients to cushion the effects resulting from the accumulated upstream flow. However, in the following years, the trend was for built areas to expand into the medium and low-slope segments, resulting in an exponential increase in areas with high flow coefficients and, therefore, flow generators that gradually converge.

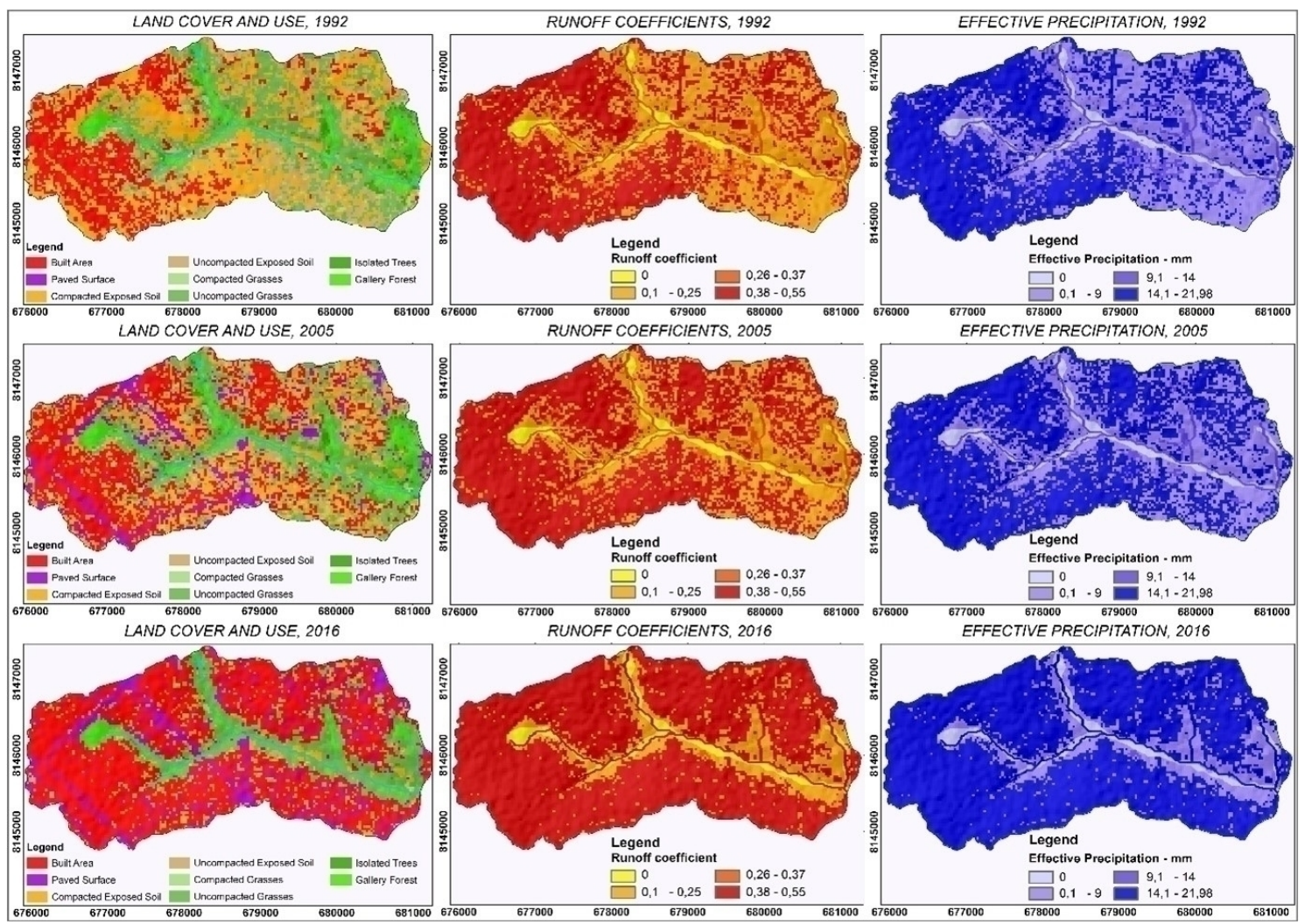

Figure 3 - Maps of land cover and use and the respective runoff and effective precipitation coefficients in 1992, 2005, and 2016.

It is worth noting that the effects of densification are not exclusively due to the increase in areas with high effective precipitation. They also result from the arrangement, both radial and immediately 
around the headwaters and drainage channels, of this high percentage of paved and built areas, which cause high runoff. The tendency to flow convergence causes the kinetic energy resulting from the volume and the speed and shorter flow concentration time to concentrate in smaller and mainly fragile areas, such as unprotected plains with sandy textured soils, which substantially increases the potential for impacts, especially in the form of erosion processes.

\section{SOIL WATERPROOFING AND THE IMPLICATIONS FOR HYDROLOGICAL DYNAMICS}

The rise in soil waterproofing has impacted directly on hydrological dynamics. Specifically, the increases in effective precipitation, speed, and consequently reduced concentration times, as well as a growth in runoff volumes, lead to an intensity apparent in environments with a greater flow convergence, such as headlands and drainage channels. As can be seen in Figure 4, in 1992, in most of the basin $(41.68 \%$ ), speeds of up to $0.56 \mathrm{~m} / \mathrm{s}$ predominated, with the maximum reaching $3.26 \mathrm{~m} / \mathrm{s}$. Since 2005 , the classes above $0.56 \mathrm{~m} / \mathrm{s}$ have been prominent, with estimates that $31.25 \%$ of the basin has speeds of $1.36 \mathrm{~m} / \mathrm{s}$ and $3.29 \mathrm{~m} / \mathrm{s}$. For 2016, the estimates of flow velocity above $1.36 \mathrm{~m} / \mathrm{s}$ covered about $42.75 \%$ of the basin and could reach up to $3.33 \mathrm{~m} / \mathrm{s}$. A direct consequence of this increase, including the area covered by the highest velocity classes, has been the reduction of the concentration time and the ensuing rise in the intensity or flow of the surface runoff.

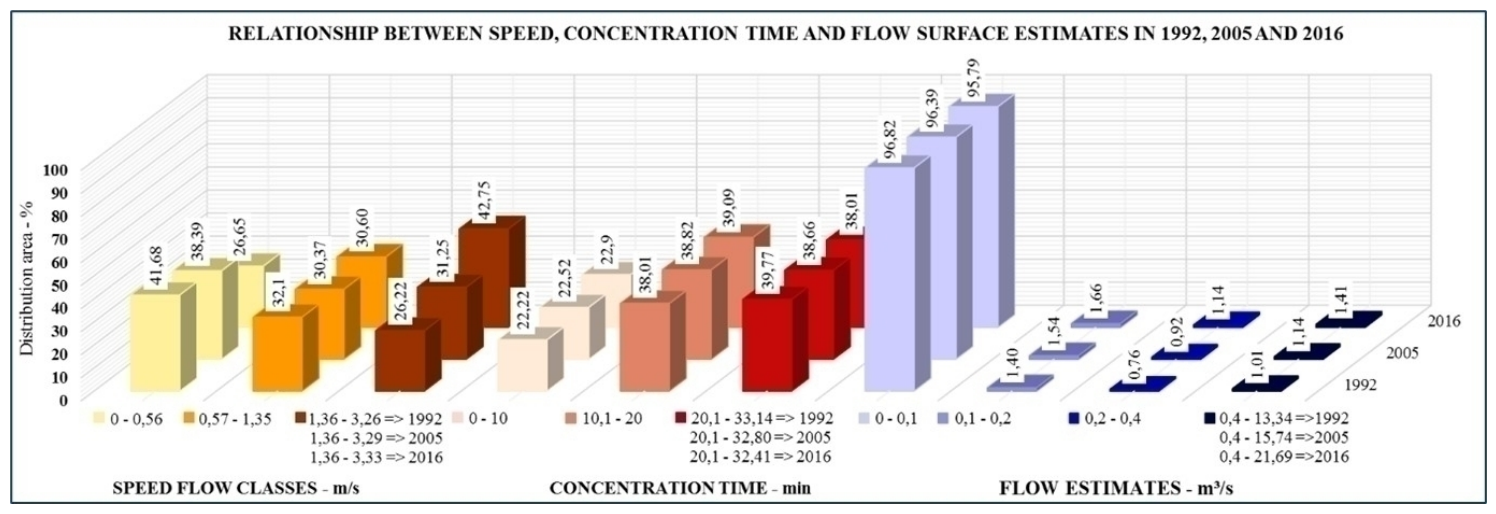

Figure 4 - Speed flow classes, concentration time, flow estimates, and respective area percentages in 1992, 2005, and 2016.

Under the conditions of land coverage and use in 1992, 33.14 minutes were required for the entire basin to contribute to the flow at the mouth. With the advance and densification of urbanization, the time for this process was reduced to 32.8 minutes in 2005 and 32.41 minutes in 2016. Considering the growth in areas with high effective precipitation, the increase in speeds, and the consequent reduction in the time of concentration of runoff, the main result has been the considerable rise in flow estimates during rain events throughout the period considered. Thus, given the conditions of land coverage and use in 1992, because of the intensity and duration of extreme rainfall events, the maximum flow estimates were $13.34 \mathrm{~m}^{3} / \mathrm{s}$ at the river mouth. Under the conditions in force in 2005 , the estimates rose to $15.74 \mathrm{~m}^{3} / \mathrm{s}$. The estimates continued to rise over the next 11 years, reaching $21.69 \mathrm{~m}^{3} / \mathrm{s}$, as systematized in Figure 4 .

The spatial expression of these changes, the resulting drops in concentration times, and the subsequent increase in velocity and runoff volume over the period are shown in Figure 5. 


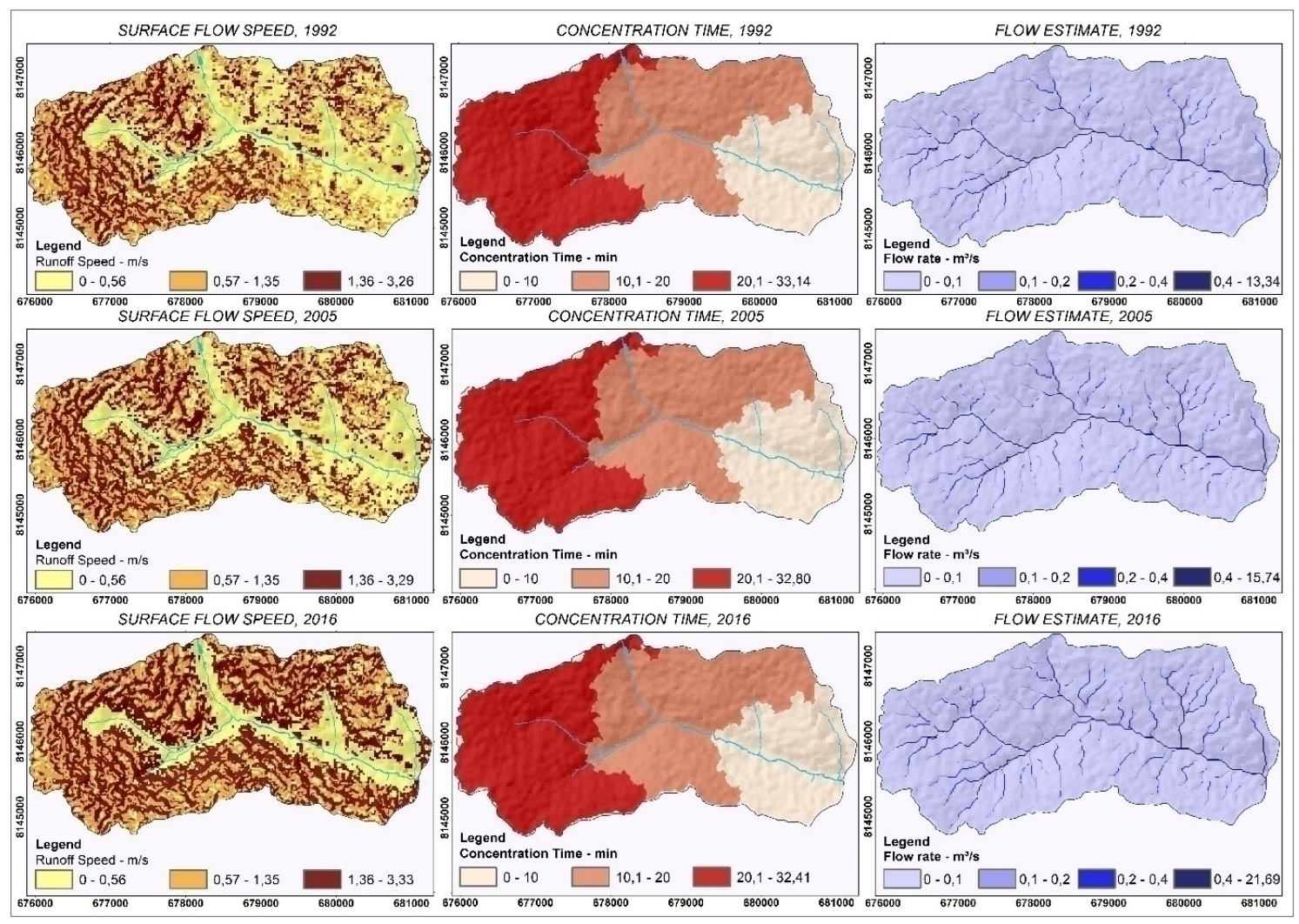

Figure 5 - Maps of velocity estimates; concentration times, and runoff volumes for 1992, 2005, and 2016.

It is important to note that in the study period, the greatest increases in velocity occurred in the medium to low slope segments, demonstrating the influence of urban density on surfaces with greater declivity in the basin's hydrological dynamics. It is also evident that the interruption of volumes over 0.2 $\mathrm{m}^{3} / \mathrm{s}$ in the vicinity of the channels is due to the existence of non-compacted grasses and some remnants of Gallery Forest. However, considering the prevalence of grasses to the detriment of natural vegetation, it is understood that the impact caused by high speeds, as well as the runoff volume were decisive in the degradation of the banks and the resulting increase in the width of the main channel.

\section{INCREASED ANTHROPIC PRESSURE AND IMBALANCES ON THE RIVER PLAIN}

Given the urban transformations and the hydrological dynamics over the years 1992, 2005, and 2016, it is clear that the hydrographic basin has undergone a sharp increase in volume, space-time concentration of surface flows, and the consequent degradation of the river plain. This situation is evidenced by the ever-increasing estimates of velocity and runoff volume, which lead to peak flows in areas of convergence, such as drainage headwaters and principally along the main channels.

As shown in Figure 6, the maximum energy estimate resulting from the volume of the runoff speed rose from $20.8 \mathrm{Mg} \cdot \mathrm{m}^{2} . \mathrm{s}^{2}$ in 1992 , to $32.2 \mathrm{Mg} \cdot \mathrm{m}^{2} . \mathrm{ss}^{2}$ in 2005 and then $44.2 \mathrm{Mg} \cdot \mathrm{m}^{2} . \mathrm{s}^{2}$ in 2016. Similarly, the main channel had an average width of $7.08 \mathrm{~m}$ in $1992,18.58 \mathrm{~m}$ in 2005 , and $71.13 \mathrm{~m}$ in 2016. From the relationship between the two quantities, it can be seen that for estimates of up to 0.2 $\mathrm{Mg} \cdot \mathrm{m}^{2} \cdot \mathrm{s}^{2}$, there was no evidence of associated erosive processes throughout the study period. However, for estimates above $0.2 \mathrm{Mg} \cdot \mathrm{m}^{2} . \mathrm{s}^{2}$, especially for the years 2005 and 2016, the relationship between the increase in the flow energy estimate and the average channel width is apparent, since 2005 it has always been over $18 \mathrm{~m}$. 


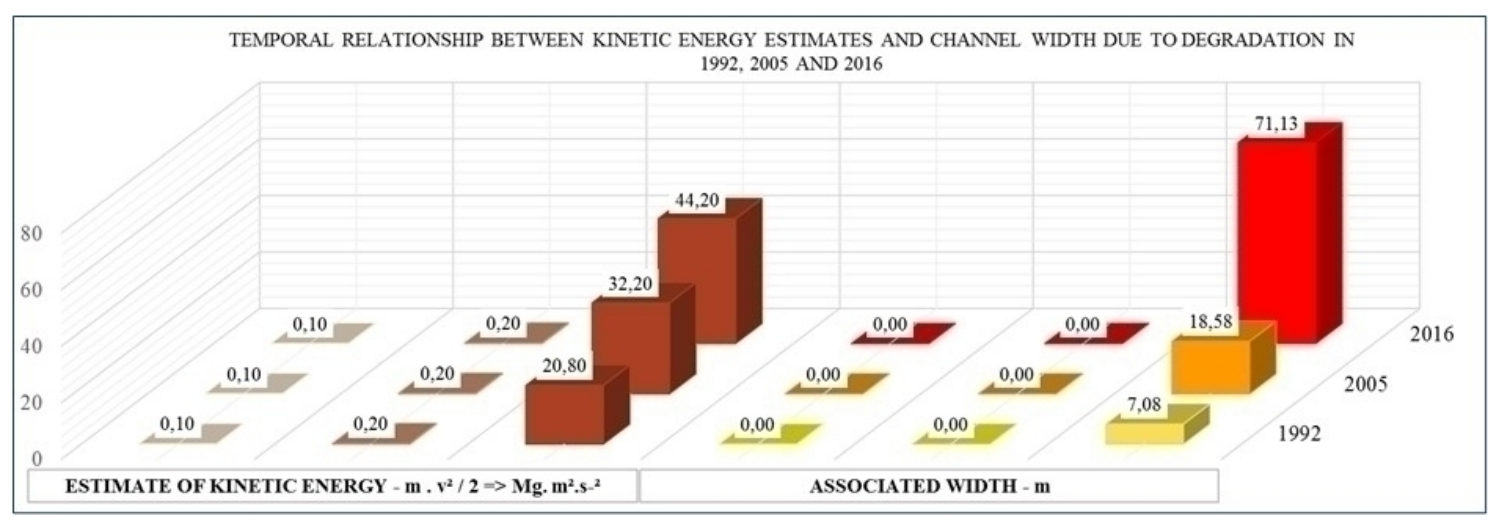

Figure 6 - Temporal relationship between the estimates of kinetic energy and the mean width of the drainage channel in the years 1992, 2005 and 2016.

The spatial distribution of the kinetic energy classes and their relationship with erosion along the main channels show that over the study period the lowest estimates gradually gave way to ones greater than $0.2 \mathrm{Mg} \cdot \mathrm{m}^{2} . \mathrm{s}^{2}$, which also started to predominate in other environments, that is, along with the drainage channels, as can be seen in Figure 7. So, in 1992, classes below $0.1 \mathrm{Mg} . \mathrm{m}^{2} . \mathrm{s}^{-2}$ occurred in flat areas, whereas those between 0.1 and $0.2 \mathrm{Mg} \cdot \mathrm{m}^{2} . \mathrm{s}^{2}$ were found on the steeper slopes, transitioning to the steepest ones, reaching up to $20.8 \mathrm{Mg} \cdot \mathrm{m}^{2} \cdot \mathrm{s}^{-2}$ along the main channel. In this situation, the width exceptionally exceeded $7.08 \mathrm{~m}$ in concave segments with evidence of more pronounced erosion.

In 2005 , the class of 0.1 to $0.2 \mathrm{Mg} \cdot \mathrm{m}^{2} . \mathrm{s}^{2}$ started to dominate along the steepest slopes and drainage headwaters, indicating a strong increase in erosive power, even in areas preceding the river plain. However, with estimates of up to $32.2 \mathrm{Mg} \cdot \mathrm{m}^{2} \cdot \mathrm{s}^{-2}$, it was along the river plain that the increase in kinetic energy was determined in the increase of erosive processes, resulting in an average width of $18.58 \mathrm{~m}$. As for 2016 , there was a gradual increase in areas with estimates of up to $0.2 \mathrm{Mg} \cdot \mathrm{m}^{2} \cdot \mathrm{s}^{2}$, especially associated with paved areas that drain directly into the main channels, as shown in Figure 7. As a result of this flow convergence at high speeds, energy estimates reached $44.2 \mathrm{Mg} \cdot \mathrm{m}^{2} . \mathrm{s}^{2}$, resulting in erosive processes that resulted in an average width of $71.13 \mathrm{~m}$.

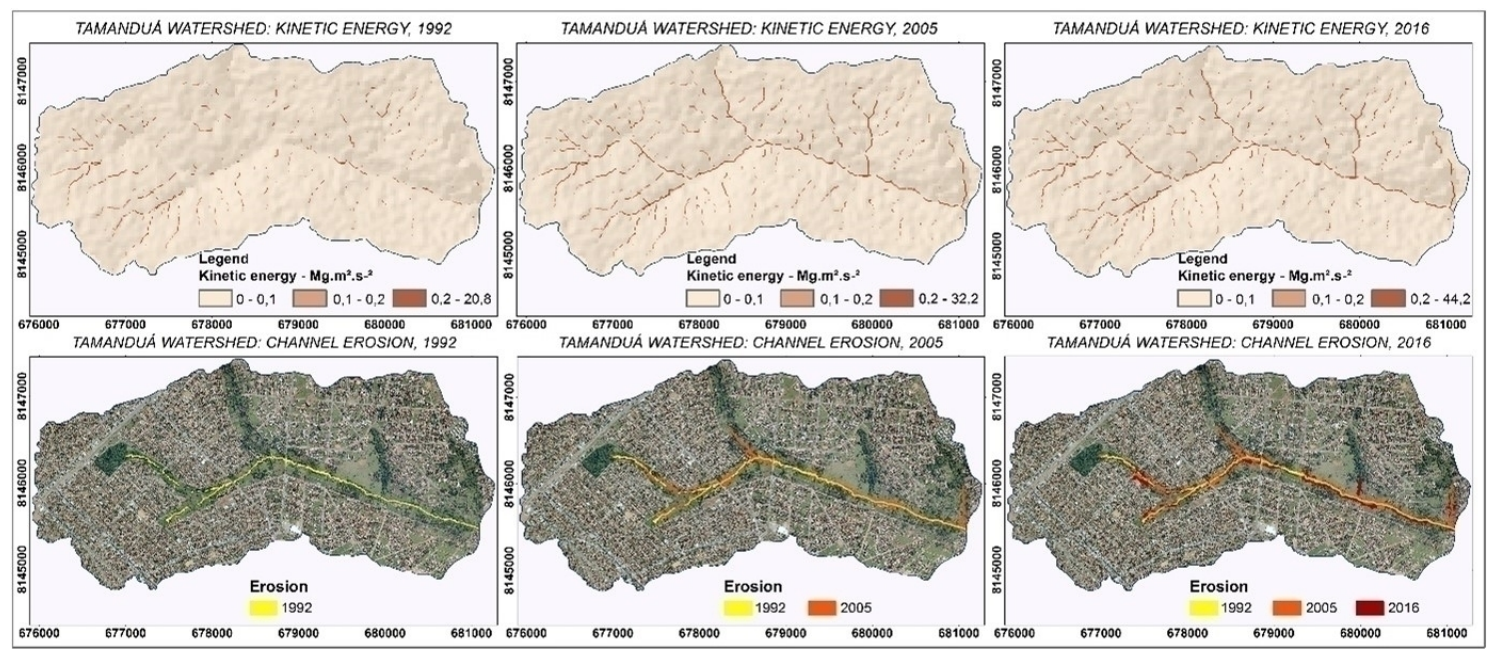

Figure 7 - the evolution of erosion by undermined banks and the consequent widening of the channel and degradation of the plain of the Tamanduá stream in the years 1992, 2005, and 2016.

A detailed analysis of the locations without riverbank vegetation that did not have established infrastructure, showed that they were the most affected by erosion processes. It is also noteworthy that these were formerly areas of specific contributions that have undergone an increase in runoff coefficients and, consequently, an escalation in flow in recent years. In these environments, erosive processes have advanced by mechanisms that undermine or erode the banks in sandy texture soils, such 
as Alluvial Neossol, sometimes overlying the clayey Alfisol. There is further deterioration in segments where erosive processes are evolving in soils such as Ultisol, that had not customarily been in contact with water flow in the channel, thus deepening the slopes. This process takes place through the erosion of the concave banks and the subsequent advance of the edges, reaching land that had not been part of the process in the past.

The process of channel degradation by erosive processes indicates that the highest rates of degradation have segments with different natural conditions in the face of anthropic changes. Thus, in part a of Figure 8, it is clear that in 1992 the channel was remarkably sinuous in the middle of the plain. However, given the tendency of the flow to increase in peak situations this morphology is not conducive to the flow of large volumes of water in increasingly shorter intervals, which necessarily leads the channel to adapt to the new conditions. This adaptation undergoes an erosive process of the concave margins and the subsequent partial deposition of the material on the convex banks. Therefore, besides becoming wider, it starts to acquire a more rectilinear character, allowing larger and larger volumes to flow in shorter intervals of time. Consequently, the segment observed in 1992 had deteriorated by 2005, as can be seen in part b of the same figure. In 2016, the same segment was already very degraded, with a notable involvement of part of the land adjacent to the channel.

In natural conditions, the predominance of metamorphic rocks such as mica schists and quartzites along the channel contributes to a lower altimetric gradient and, consequently, is conducive to the occurrence of hydromorphic soils, such as Alfisol, and alluvial soils such as the Alluvial Neossol. As a result, over almost all the segments with a low altimetric gradient, there was a significant widening due to the lower resistance of the prevailing soils. Due to its sandy character and easy disintegration and transport, the Alluvial Neossol contributed significantly to the widening of the channel and the ensuing degradation of the plain.
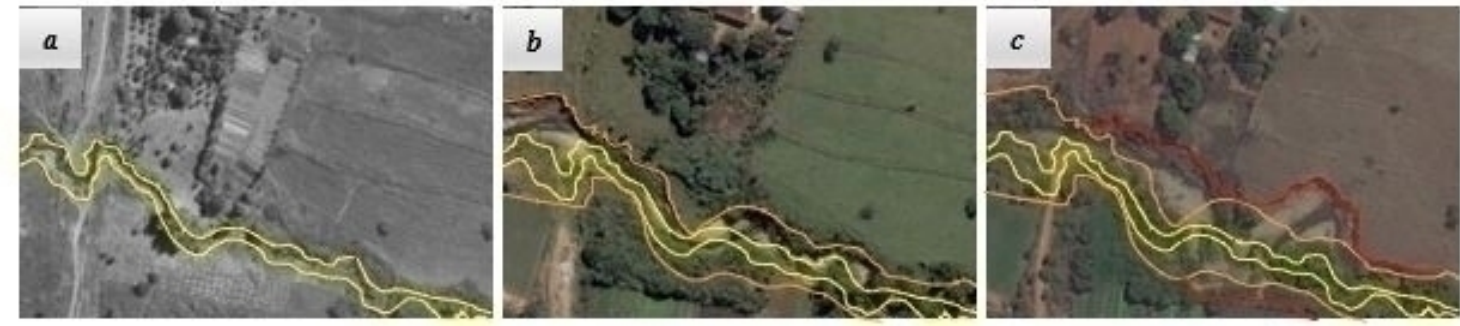

Figure 8 - Situation of a segment with a low altimetric gradient of the drainage channel in 1992 ( a ); 2005 ( b ), and 2016 (c ).

In addition to the low gradient segments, others also proved to be conducive to erosive processes. This occurred at the confluence of channels, the edges of which were intercepted by lineaments of flows from areas that underwent major changes in coverage and use during the period considered, as illustrated in Figure 9. So, in part a there was a convergence point of channels that was still very preserved in 1992, with a low flow estimate, as well as the absence of any peak flow. In 2005, the flow estimate had risen sharply and there was already a noticeable indentation or edge concavity due to the flow interception and consequent undermining of the sides. In 2016, the flow interception continued, and the bank became more concave as the edge retreat progressed, significantly widening the segment in question.
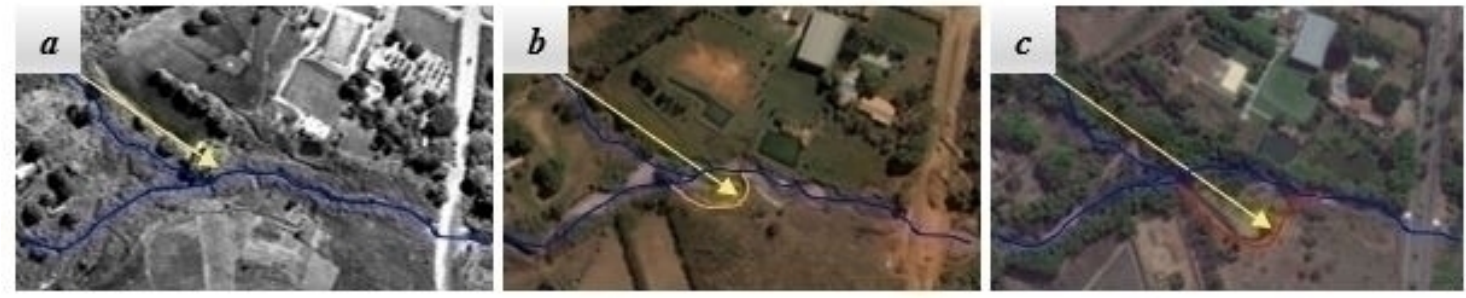

Figure 9 - The point of confluence of two drainage channels in 1992 (a), in 2005 (b); and 2016 (c). 
The accentuated process of urban density over the last twenty-four years can be highlighted as the main factor potentializing the process, as is evident in the maps of land coverage and use and the respective flow coefficients and effective precipitation presented in Figure 3.

The cumulative effect of these changes, such as increased precipitation intensity, increased flow coefficients, increased speeds, and flow volume, as well as the resulting reduction in concentration time along a hydrographic basin, implies an intensification in the surface hydrological processes. These processes occur in the form of increased pressure on the sides of the slopes at peak flow times and can be considered as the spatial and temporal expression of the increase in anthropic pressure, especially in times of rain. After the pluviometric events, the pressure on the channels is relieved and they are then exposed to the full regime of the banks, which involves more lateral erosion due to the undermining of the edges.

This dynamic of rising and falling pressure necessarily leads the river system to adapt to the new pattern of behavior of the water flow. A priori, such an adaptation means changes, especially in the width destined to the water flow in peak flow situations. Consequently, it implies imbalances along the main channels in the form of degradation of the floodplain. However, it is understood that these imbalances can be reduced by installing retention basins, as well as barriers, both flow regulators, along the slopes and main tributary channels, respectively, to preserve part of the pre-occupation concentration time, especially along the slopes

\section{CONCLUSION}

The urban expansion and densification process is an inherent evolution in the growth of cities, especially those in large metropolitan regions. This expansion necessarily means changes in the pace of physical processes, especially hydrological ones. However, there is criticism of the lack of rigorous studies that enable more accurate prognoses about the possible impacts regarding the implantation of subdivisions and the resulting alteration of the properties of the soil and terrain, their interaction with rainfall events and their relationship with the behavior of surface water.

Given the above, we highlight the possibility of applying this methodology in geographic studies focused on urban planning to measure the likely impacts resulting from the urban expansion and densification process more accurately. Considering that it involves the main variables that evaluate the functioning of the hydrological system, it is possible to assess the effects of soil compaction and waterproofing and, consequently, define the most appropriate mitigating or remedial measures. These include the containment of the spatial-temporal convergence of superficial water flows, new laws that allocate an adequate percentage of area for infiltration in each household, as well as the definition of structures designed to receive high rainfall volumes.

As observed in recent years, cities have grown through urban expansion and/or densification. Thus, the existence of increasingly accurate and precise cartographic materials, as well as constantly improving methodologies, make it possible to dimension the impacts of this process with considerable precision.

\section{REFERENCES}

BORGES, E. M. B.; CUNHA, D. F. Dinâmica imobiliária recente e seus impactos na reconfiguração urbana e socioespacial da Região Metropolitana de Goiânia. In: SEMINÁRIO INTERNACIONAL DE ARQUITETURA, TECNOLOGIA E PROJETO, 2015, Anápolis. Anais... Anápolis: UEG, 2015.

CAMARGO, C. E. S.; AMORIM, M. C. C. T. Qualidade ambiental e adensamento urbano na cidade de Presidente Prudente - SP. Scripta Nova - Revista Eletrónica de Geografía y Ciencias Sociales. Universitad de Barcelona, v. 9, n. 194, p. 1 - 11, 2005. http://dx.doi.org/10.1344/sn2005.9.962.

EUCLYDES, H.P. Saneamento agrícola. Atenuação de cheias: metodologia e projeto. Belo Horizonte: Rural Minas, 1987. 320 p.

FERREIRA, L. C. G. Uma reflexão sobre a expansão e a mobilidade urbana: Uma análise do Plano 
Diretor de Goiânia - GO. OBSERVATORIUM: Revista Eletrônica de Geografia. v. 5, n. 15, p. 62 - 86, 2013.

FHA. Federal Highway Administration. Urban Drainage Design Manual, Hydraulic Engineering. 3. Ed. Washington D. C.: National Highway Institute, USDT, 2013. p. 478.

FUCK, R. A. et al. The basement of the Brasília Fold Belt and the Goiás Magmatic Arc. In: CORDANI, U. G.; MILANI, E. J.; THOMAZ-FILHO, A.; CAMPOS, D. A. (Ed.). The Tectonic Evolution of South America. Rio de Janeiro, p. 195 - 229. 2000.

GRIFFITHS, J. A.; ZHU, F. F.; CHAN, F. K. S.; HIGGITT, D. L. Modelling the impact of sea-level rise on urban flood probability in SE China. Geoscience Frontiers, In Press. 2018. https://doi.org/10.1016/j.gsf.2018.02.012.

GUZHA, A. C.; RUFINO, M. C,; OKOTH,; JACOBS,; NÓBREGA, R. L. B. Impacts of land use and land cover change on surface runoff, discharge and low flows: Evidence from East Africa. Journal of Hydrology: Regional Studies, v. 15, p. 49 - 67. 2018. https://doi.org/10.1016/j.ejrh.2017.11.005.

HAMMOND, M. J.; CHEN, A. S.; DJORDJEVIĆ, S.; BUTLER, D.; MARK, O. Urban flood impact assessment: A state-of-the-art review. Urban Water Journal, v. 12. p. 14 - 29. 2013. https://doi.org/10.1080/1573062X.2013.857421.

INMET - Instituto Nacional de Meteorologia. Rede de Estações, Automáticas, Gráficos, Estação A002, Goiânia. Brasília, DF, Brasil. Disponível em . Acesso em: 21 de maio de 2017.

KOCORNIK-MINA, A.; McDERMOTT, T.; MICHAELS, G.; RAUCH, F. Flooded cities. London: Grantham Research Institute on Climate Change and the Environment. Working Paper n. 248, 2015. 45 p.

KUICHLING, E. The relation between the rainfall and the discharger of sewers in populous districts. Transactions of the American Society of Civil Engineers, v. 20, n. 1, p. 1 -60. 1889.

LACERDA FILHO, J. V.; SOUZA, J. O.; REZENDE, A.; SILVA, A. Programa Levantamentos Geológicos Básicos do Brasil - Geologia e Recursos Minerais do Estado de Goiás e Distrito Federal. Goiânia: CPRM - Serviço Geológico do Brasil, 1999, 269 p.

LECHIU, B. C. G.; FILHO, P. C. O.; SOUSA, J. B. Utilização de imagens orbitais de alta resolução em superfícies com níveis distintos de impermeabilização do solo urbano: caso Irati - PR. Semina: Ciências Exatas e Tecnológicas, Londrina, v. 33, n. 2, p. $127-140,2012$. http://dx.doi.org/10.5433/1679-0375.2012v33n2p127.

LIMA, A. P.; AMORIM, M. C. C. T. Análise de episódios de alagamentos e inundações urbanas na cidade de São Carlos a partir de notícias de jornal. Revista Brasileira de Climatologia. v. 15, ano 10, p. 182 - 2004, 2014. http://dx.doi.org/10.5380/abclima.v15i0.33406.

LIN, S.; SUN, J.; MARINOVA, D.; ZHAO, D. Effects of Population and Land Urbanization on China's Environmental Impact: Empirical Analysis Based on The Extended STIRPAT Model. Sustainability, MDPI Open Access Journal, v. 9, n. 825, p. 1 - 21, 2017. http://dx.doi.org/ 10.3390/su9050825.

LUIZ, G. C.; ROMÃO, P. A. Interação solo-atmosfera e processos de inundação e alagamentos na cidade de Goiânia-GO. Revista Brasileira de Geografia Física, v. 12, n. 05, p. 1891 - 1903, 2019. DOI: https://doi.org/10.26848/rbgf.v12.5.p1891-1903.

MOHAJERI, N.; GUDMUNDSSON, A.; SCARTEZZINI. J. L. Expansion and densification of cities: linking urban form to urban ecology. In: International Conference on Future Building e Districts Sustainability From Nano to Urban Scale, 2015, Lausanne, Switzerland. École polytechnique fédérale de Lausanne, 2015.

MONTEIRO, C. A. F. Notas para o estudo do clima do Centro-Oeste Brasileiro. Revista Brasileira de Geografia, p. 22 - 45, jan - mar, 1951. 
MUKHERJEE, D. Effect of urbanization on flood - a review with recent flood in Chennai (INDIA). International Journal of Engineering Sciences \& Research Technology, v. 5, p. 451 - 455, 2016. https://doi.org/10.5281/zenodo.57002.

MULVANEY, T. J. On the use of self-registering rain and flood gauges in making observations of the relations of rainfall and flood dischargers in a given catchment. Trans. Inst. Civil Eng. Ireland, v. 4, p. 18-33, 1851.

NRCS. National Resources Conservation Service. Estimation of direct runoff from storm rainfall. In: . National Engineering Handbook Hidrology Chapters. NRCS: Washington, D. C., 1997. 79 p.

NUNES, L. H. Urbanização e desastres naturais, abrangência América do Sul. São Paulo: Oficina de Textos, 2015, $112 \mathrm{p}$.

NUNES, E. D.; BORBA, L. Avaliação dos efeitos do adensamento urbano na dinâmica hidrológica de bacias hidrográficas - Aparecida de Goiânia - GO. Boletim Goiano de Geografia, Goiânia, v. 38, n. 2, p. 428 - 449, 2018. https://doi.org/10.5216/bgg.v38i2.54617.

OJIMA, R. Novos contornos do crescimento urbano brasileiro? O conceito de urban sprawl e os desafios para o planejamento regional e ambiental. Geographia, Rio de Janeiro, v. 10, n. 19, p. 46 - 59, 2008. https://doi.org/10.22409/geographia.v10i19.234.

OLIVEIRA, L. F. C. et al. Intensidade-duração-frequência de chuvas intensas para localidades no estado de Goiás e Distrito Federal. Pesquisa Agropecuária Tropical, Goiânia, v. 35, n. 1, p. 13 - 18, 2005.

OLIVEIRA, R. B. et al. Distribuição espacial das áreas de ocorrências a processos de alagamentos e inundações na cidade de Goiânia-GO. In. XI Simpósio Brasileiro de Climatologia Geográfica, 2014, Curitiba. Anais...Curitiba: UFPR, 2014.

PASQUALOTTO, N.; SENA, M, M. Impactos ambientais urbanos no Brasil e os caminhos para cidades sustentáveis. Educação Ambiental em Ação, Novo Hamburgo, n. 61, Ano XVI, p. 1 - 9, 2017.

PINTO, J. V. C. Desconstruindo a "cidade dormitório": centralidades e espaço intra-urbano de Aparecida de Goiânia. Mercator - Revista de Geografia da UFC, n. 16, ano 8, p. 45 - 59, 2009. https://doi.org/10.4215/rm2009.0816.0004.

PORTO, R. L. L. Escoamento superficial direto. In: TUCCI, C. D. M.; PORTO, R. L. L.; BARROS, M T.de. (Org.). Drenagem urbana. Porto Alegre: ABRH, 1995. p. 107 - 162. (v. 5).

PORTO, R. L. L.; ZAHED, K.; TUCCI, C.; BIDONE, F. Drenagem urbana. In: TUCCI, C. E. M. (Org.). Hidrologia: ciência e aplicação. Porto Alegre: ABRH, 2004. p. 805-847.

RODRIGUES, A. P. et al. Caracterização do meio físico, dos recursos minerais e hídricos do município de Aparecida de Goiânia. Goiânia: Superintendência de Geologia e Mineração, 2005. 107 p.

RUBINATO, M.; MARTINS, R.; SHUCKSMITH, J. D. Quantification of energy losses at a surcharging manhole, Urban Water Journal, v. 15, n. 3, p. $234 \quad-\quad 241,2018$. https://doi.org/10.1080/1573062X.2018.1424217.

SANTOS, K. A.; RUFINO, I. A. A.; FILHO, M. N. M. B. Impactos da ocupação urbana na permeabilidade do solo: o caso de uma área de urbanização consolidada em Campina Grande - PB. Engenharia Sanitária e Ambiental, v. 22, $\quad$ n. $\quad 5, \quad$ p. $943 \quad-\quad 952,2017$. https://doi.org/10.1590/S1413-41522016146661.

SCS. Soil Conservation Service. Design hydrographs, section 4, hydrology. In: MOKUS, V. National Engineering Handbook, USDA, Washington D. C., 1971. 127 p.

SILVA, L. S.; TRAVASSOS, L. Problemas ambientais urbanos: desafios para a elaboração de políticas públicas integradas. Cadernos Metrópole, São Paulo, n. 19, p. $27 \quad-\quad 47,2008$. http://dx.doi.org/10.1590/8708.

SU, W.; YE, G.; YAO, S.; YANG, G. Urban land pattern impacts on floods in a New District of China. 
Sustainability, MDPI Open Access Journal, v. 6, p. $6488 \quad-\quad 6508,2014$. https://doi.org/10.3390/su6106488.

TRIPATHI, R. et al. Climate change, urban development, and community perception of an extreme flood: A case study of Vernonia, Oregon, USA. Applied Geography, v. 46, p. 137 - 146, 2014. https://doi.org/10.1016/j.apgeog.2013.11.007.

TUCCI, C. E. M.; MARQUES, D. M. L. da M. Avaliação e controle da drenagem urbana. Porto Alegre: Ed. UFRGS, 2001. $558 \mathrm{p}$.

TUCCI, C. E. M. Inundações urbanas. Coleção Associação Brasileira de Recursos Hídricos, v. 11. Porto Alegre: ABRJ/RHAMA, 2016. 389 p.

VILLELA, S. M.; MATTOS, A. Hidrologia aplicada. São Paulo: Mc Graw-Hill do Brasil, 1975. 245 p.

WEBBER, J. L. et al. Rapid assessment of surface-water flood-management options in urban catchments, Urban Water Journal, v. $15, \quad$ n. $3, \quad$ p. $210 \quad-\quad 217,2018$. https://doi.org/10.1080/1573062X.2018.1424212.

WOLLMAN, C. A. Revisão teórico-conceitual do estudo das enchentes nas linhas de pesquisa da Geografia Física. Revista Eletrônica Geoaraguaia, Barra do Garças, v. 5, n. 1, p. 27 - 45, 2015. 